\title{
MILAN JAMES KOPAC
}

\author{
(1903-1989)
}

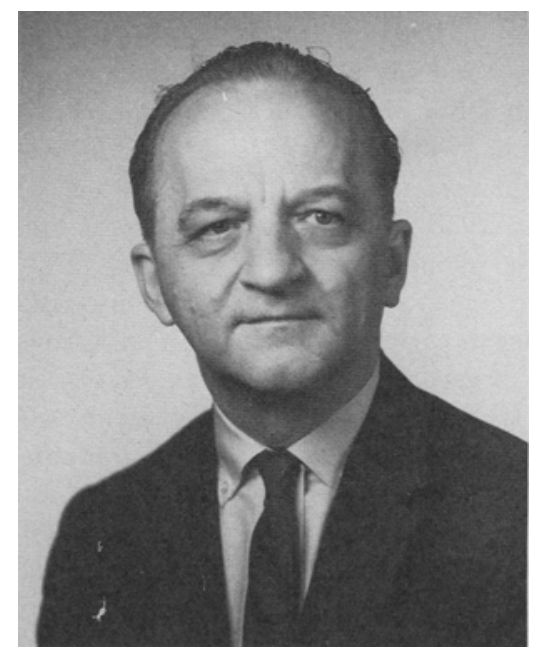

Milan James Kopac, Professor of Biology at New York University, Professor Emeritus of Biology since 1973, distinguished research biologist and administrator, former TCA member, died in Lincoln, Nebraska on November 2, 1989 at the age of 86 . His students, associates and friends all affectionately knew him as "Mike" or "MJK." Born in Ravena, Nebraska in 1903, he was torn between his concurrent interest in science and music. In his early career, Mike became an accomplished musician with a profound love for jazz. He used his musical talent to support himself through the University of Nebraska, playing the piano, saxophone and the accordion with bands in the dance halls of many midwestern towns. He was known as "Mike Kopac: King of the Ivories." He played late into the night in towns from Marysville, Kansas to Yanton, South Dakota. He would routinely escort his fellow musicians home and even make it to class on time the next morning.

Mike earned his B.Sc. degree in 1927 from the University of Nebraska at Lincoln. Because of his increasing fervor for science, he set aside his musical career, became a graduate student and earned a Master's degree in 1929 at Nebraska with Dr. Harold Manter, a renowned parasitologist. He then accepted a fellowship at Johns Hopkins University, which he resigned after only one week because he did not have facilities to do research involving cell microsurgery. Shortly thereafter, he was awarded a fellowship at the University of California at Berkeley, where a micromanipulator was made available for his use and thus allowed him to begin a lifelong commitment to the design and application of the micromanipulator for research on the cell. He earned his Ph.D. degree at Berkeley in 1934.

Following his Ph.D. work, Mike received a National Research Council fellowship to study at New York University with the renowned biologist and micrurgist, Dr. Robert Chambers. This fellowship was a highlight of his career and the beginning of 43 years of distinguished achievement in the field of cell microsurgery and dedication to New York University. He served NYU in many different capacities and became a full professor in 1949. He was Head of the AllUniversity Department of Biology from 1963 to 1973. In 1948, he established the Robert Chambers Laboratory for Cell Microsurgery at NYU in honor of Dr. Chambers who had died earlier. Mike suffered a stroke in 1972 but recovered sufficiently to continue many of his previous activities until he retired in 1973 as Head of his department. For the next several years thereafter, he was assisted in his work in The Robert Chambers Laboratory by his former students, Drs. Ralph and Betty (Fong) Zuzulo.

Mike's contributions as a scientist, administrator, and teacher are noteworthy. He published more than 150 research papers in cellular microsurgery, cytochemistry, genetics, cancer cytology and cell physiology. Cell culture figured prominently in his research. He designed, constructed and improved some of the most intricate microsurgical instruments in the world. He was among the first investigators to apply video techniques and image analysis of microsurgical specimens. He also designed the first semi-automatic micromanipulator driven by servo-motors and simple computer circuits.

He also pioneered a mechanical device for the repetitive microinjection of subnanoliter volumes of substances into cells. Presently, interest in the microinjection of DNA into living cells has furthered the development and commercial production of a variety of picoliter microinjection devices.

Mike's life in science was multifaceted. He had a fervent desire to nurture and attract young people into science. For outstanding scientific accomplishments, he received an honorary Doctor of Science degree from his alma mater, the University of Nebraska, 1962.

Mike's decision to dedicate his life completely to science and his commitment to interest youth in science led to a wide variety of personal experiences and achievements. He was elected to membership in the Sigma $\mathrm{Xi}$-University of Nebraska Chapter in 1927. He later served as vice-president and president of the NYU Chapter (1935-1937). One of his early and unforgettable experiences was his research at the 
Tortuga Laboratory of the Carnegie Institution of Washington. He also cherished the 15 summers he spent at the Woods Hole Marine Biological Research Laboratory with Dr. Chambers. Mike always praised the Gordon Research Conferences and chaired one on Cancer.

Two of Mike's significant outside professional activities involved the New York Academy of Sciences and his deep commitment to cancer research. He became an active member of the NY Academy of Sciences in 1945, and in 1946, he was elected a Fellow in recognition of his achievements and contributions. He served as vice president in 1958 and was elected president in 1960. Thereafter, he served as member of its Board of Trustees and Scientific Council.

Mike's ardent interest in cancer research began early in his career. He also served on various committees fostering cancer research. He was consultant for the National Cancer Institute of the National Institutes of Health for many years, a member of the Scientific Advisory Committee (1951-73) of the Damon Runyon-Walter Winchell Cancer Research Fund and its chairman (1968-69), and a member of the Research Advisory Council of the Cancer Institute (Miami, FL) and of the Advisory Committee for Research Grants of the American Cancer Society. In addition, Mike was a member of the NIH panel on Cellular Physiology, the Committee on Growth, and of the panel to review fellowships in physiology. He was also a founder and member of both the Society of Cell Biology and Inter-Society Cytology Council.

As an educator, Mike was a dynamic teacher, who was honored with the "Great Teacher Award" at NYU in 1971. He taught biochemistry, cell physiology and microsurgery at both the undergraduate and graduate levels, and mandated the policy that all biology faculty teach at both undergraduate and graduate levels. He insisted that young students be exposed to the thoughts and insights of established scientists. Over the years, Mike was the Ph.D. degree mentor of more than 95 students, and many earned the Master's degree under his tutelage. Many of his former students are members of the Tissue Culture Association.

Mike encouraged and facilitated the transfer of the Robert Chambers Laboratory to the Biology Department of The City College, The City University of New York, under the supervision of Ralph and Betty Zuzulo. His confidence in their being able to continue the traditions he so ably established is a living memorial to him as a teacher and warm human being. The facility continues to serve graduate students, outstanding undergraduates, and members of the scientific, medical and industrial communities. Contributions to the Milan J. Kopac Scholarship funds may be made to the Chambers Laboratory, Department of Biology, The City College, Convent Avenue at 138th Street, New York, NY 10031.

If a measure of a man is the number of scientists and scholars who continue in the footsteps of their mentor, then Mike J. Kopac surely ranks high as an exemplary educator, scientist and man.

Ralph and Betty Zuzulo The City College, NY
Carlton H. Nadolney

U.S. Environmental

Protection Agency 